\title{
Jürg Fischer 1936-2018 - in memoriam
}

\author{
Gaston Adamek
}

Flurstrasse 25, 3014 Bern, Switzerland. E-Mail: g.adamek@bluewin.ch

After a full and varied life, PD Dr. Jürg Fischer died in 2018, secluded in Ascona, southern Switzerland. Many elder researchers had known him from the International Symposia on Chironomidae, by actively corresponding with him or through his publications.

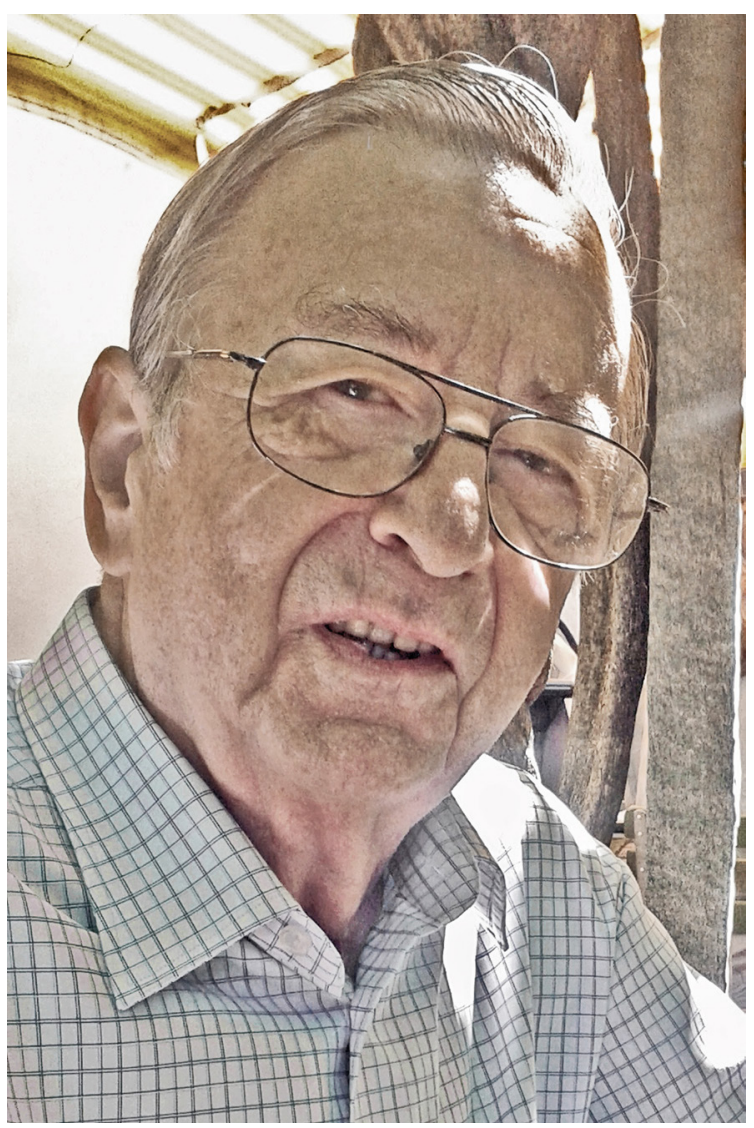

Jürg Fischer in Ascona, 2015. Photo: Barbara Streit-Fischer

Jürg Fischer was born in Bern and received his education as a primary school teacher and then as a secondary school teacher. He taught at various levels for several years in different schools in the canton of Bern before studying zoology, botany and chemistry at the Faculty of Natural Sciences (University of Bern). Already during his diploma thesis as well as his dissertation, was he dealing with chironomids in the department of Prof. Siegfried Rosin (Fischer 1978) at the Zoological Institute. After having finished his dissertation, "On the Reproductive Biology of Chironomus nuditarsis Str.", he worked as a senior assistant in the aforementioned department and made essential contributions to its development. Jürg Fischer did not only have an enormously broad knowledge, but he was also very talented in practical/technical matters, which proved its worth in the development of a carefully maintained and well thought-out chironomid breeding program and the construction of sophisticated experimental set-ups. Influenced by Rosin's mathematical and biostatistical knowledge, his experiments were always far-sightedly planned with regard to their verification. After his habilitation, Fischer became heavily involved in the teaching of zoology, especially ecological genetics. Collaborators of the department regarded Jürg Fischer as a reliable colleague and friend. Thanks to his pedagogical-didactic skill, his teach-

ing at the university was very popular among biology students as well as medical or pharmaceutical students. While many truly appreciated his open and direct expression of opinion, others were less pleased with this characteristic. His insect courses and excursions were particularly well attended. Jürg Fischer was also interested in other areas of zoology. He collaborated, for example, several times in outdoor studies on the rock ptarmigan (Lagopus muta) in the Swiss Alps.

His list of publications manifests two main areas of chironomid research:

(1) Effects of chromosomal structures or mutations on reproduction and selection. For the time being, this work was mostly done in cooperation with Siegfried Rosin. After a six-month stay at the University of British Columbia in Vancouver, investigations were carried out in collaboration with researchers from Bern, with Dr. Herbert Tichy in Tübingen and especially with Prof. Paraskeva Michailova in Sofia as well as with Russian researchers. Particular emphasis should be laid on his original work on translocations, which was made possible thanks to his ability (acquired with patience and perseverance) to mate midges individually. Unique were, among other things, his translocation 'chromosome rings' of up to all eight chromosomes of Chironomus nuditarsis, produced from several translocation breedings; they thus provided fundamentals for population and species vitality and for species evolution. 
(2) Thanks to Fischer's basic research on the development and physiology of Chironomus plumosus and Ch. nuditarsis in particular, several studies on dormancy and eclosion activity could be carried out.

Due to the early death of Prof. Rosin and the subsequent failure to reoccupy the professorship, Jürg Fischer's internal working conditions were unfortunately to become very difficult for years, above all due to resentment and even bullying. He found consolation in his good relations with the international family of chironomid researchers. However, his early withdrawal from chironomid research was something he could not really cope with for the rest of his life.

Nevertheless, his dry sense of humour continued part of his personality. Furthermore, Jürg Fischer's ability to remember and memorize was impressive: He could quote longer literary texts or poems at will and by heart on any appropriate occasions; who else but $\varphi$ (his usual signature abbreviation) could, just for fun, correctly recite 100 decimal places of the mathematical constant $\pi$. In addition to his manifold biological commitment, he played various musical instruments and thus counterbalanced his professional work. For years, Jürg Fischer was known in the Bernese jazz scene as an excellent bass player.

He always stayed loyal to his friends despite his gradual withdrawal in his later years, a behaviour probably also caused by health reasons. Until his death, Jürg Fischer received unwavering support from his family, consisting of his partner, his children and grandchildren. His work and his enthusiasm are an incentive for us to continue working in his spirit. In many ways, $\varphi$ remains a role model for us all.

Acknowledgements - Many thanks to Barbara and Daniel Streit-Fischer and Andreas Bossert for helpful information and to Erich Blatter for the careful correction of the manuscript.

\section{Publications by Jürg Fischer on Chironomidae}

Fischer, J. 1965. Beiträge zur Biologie von Chironomus nuditarsis. Zusammenfassung von Beobachtungen und Untersuchungen aus der Zeit vom Sommer 1963 bis zum Frühjahr 1965. Lizentiatsarbeit. Zoologisches Institut der Universität Bern. 82 p.

Rosin, S. and Fischer, J. 1965. Geschlechtsgekoppelte Inversionen bei Chironomus nuditarsis Str. - Archiv der Julius Klaus-Stiftung 40(1-4): ,26-35'.

Rosin, S. and Fischer, J. 1966. Über eine Translokation aus einer Wildpopulation von Chironomus nuditarsis Str. - Archiv der Julius Klaus-Stiftung 41(2-4): ,37-44‘.

Fischer, J. and Rosin, S. 1967. Bastarde zwischen Chironomus plumosus L. und Ch. nuditarsis Str. - Archiv der Julius Klaus-Stiftung 42(3-4): ,30-42‘.

Fischer, J. 1968. Zur Biologie von Chironomus nuditarsis und Ch. plumosus L. Inaugural-Dissertation. Phil.-nat. Fakultät der Universität Bern. 63 p.

Fischer, J. and Rosin, S. 1968. Einfluss von Licht und Temperatur auf die Schlüpf-Aktivität von Chironomus nuditarsis Str. - Revue suisse de Zoologie 75: 538-549. https://www.biodiversitylibrary.org/ page/43208026

Rosin, S. and Fischer, J. 1968. Zum Selektionswert verschiedener chromosomaler Strukturtypen von Chironomus nuditarsis Str. - Archiv der Julius Klaus-Stiftung 43(3-4): ,31-40‘.

Fischer, J. 1969. Zur Fortpflanzungsbiologie von Chironomus nuditarsis Str. - Revue suisse de Zoologie 76: 23-55. https://www.biodiversitylibrary.org/page/43220769

Fischer, J. and Rosin, S. 1969. Das larvale Wachsturn von Chironomus nuditarsis Str. - Revue suisse de Zoologie 76: 727-734. https://www.biodiversitylibrary.org/page/43221495

Rosin, S. and Fischer, J. 1972. Y-Polymorphismus bei Chironomus nuditarsis. - Archiv für Genetik 45: 100.

Rosin, S. and Fischer, J. 1972. Polymorphisrnus des Realisators für männliches Geschlecht bei Chironomus. - Revue suisse de Zoologie 79(Fasc.suppl.): 119-141.

Fischer, J. 1974. Experimentelle Beiträge zur Ökologie von Chironomus (Diptera). I. Dormanz bei Chironomus nuditarsis und Ch. plumosus. - Oecologia 16: 73-95. https://doi.org/10.1007/BF00345089

Bertogg, A. and Fischer, J. 1978. Zur Kotabgabe-Intensität und Bewegungsaktivität dormanter und nichtdormanter Larven von Chironomus plumosus (Diptera). - Revue suisse de Zoologie 85: 817-822. https:// www.biodiversitylibrary.org/page/41326819 
Fischer, J. 1978. Zum Problem der Chromosomen-Evolution durch Translokationen bei Chironomus (Diptera). - Archiv für Genetik 51: 73-98.

Fischer, J. 1978. Siegfried Rosin 1913-1976. - Chironomus 2: 6-7.

Fischer J. 1978. Die Zuckmücken des Wohlensees (Chironomus). In Naturforschende Gesellschaft in Bern (Ed.) Die Aare und ihre Wasser. NGB, pp. 15-16.

Fischer, J. and Tichy, H. 1978. Über eine Heterochromatin-Mutation aus einer Wildpopulation von Chironomus nuditarsis. I. Zur Funktion des veränderten Genom-Abschnittes. - Archiv für Genetik 51: 244.

Pulver, U. and Fischer, J. 1978. Über eine Heterochromatin-Mutation aus einer Wildpopulation von Chironomus nuditarsis. II. Zum Replikationsverhalten des veränderten GenomAbschnittes. - Archiv für Genetik 51: 244.

Ineichen, H., Riesen-Willi, U. and Fischer, J. 1979. Experimental Contributions to the Ecology of Chironomus (Diptera). II. The Influence of the Photoperiod on the Development of Chironomus plumosus in the 4th Larval Instar. - Oecologia 39: 161-183. https://doi.org/10.1007/BF00348066

Reist, A. and Fischer, J. 1979. Ökologische und biometrische Untersuchungen an Chironomus-Larven (Diptera) des Wohlensees bei Bern. - Revue suisse de Zoologie 86: 893-899. https://www.biodiversitylibrary.org/page/41328985

Adamek, G. and Fischer, J. 1980. Zur Atmungsintensität, Bewegungsaktivität und Herztätigkeit nicht dormanter und dormanter Larven von Chironomus plumosus. In Murrey, D.A.(Ed.) Chironomidae - ecology, systematics, cytology and physiology. Proceedings of the $7^{\text {th }}$ International Symposium on Chironomidae, Dublin, August 1979. Pergamon Press, pp. 53-58.

Fischer, J. and Tichy, H. 1980. Über eine Heterochromatin-Mutation aus einer Wildpopulation von Chironomus nuditarsis. I. Zur Funktion des veränderten Genom-Abschnittes. - Genetica 54: 41-43. https:// doi.org/10.1007/BF00122406

Pulver, U. and Fischer, J. 1980. Über eine Heterochromatin-Mutation aus einer Wildpopulation von Chironomus nuditarsis. II. Zum Replikationsverhalten des veränderten Genomabschnittes. - Genetica 54: 87-90. https://doi.org/10.1007/BF00122412

Michailova, P. and Fischer, J. 1983. Cytogenetic studies on Chironomus plumosus L. (Diptera, Chironomidae) from different populations and their experimental hybrids. - Memoirs of the American Entomological Society 34: 211-221. https://www.biodiversitylibrary.org/page/38623081

Adamek, G. and Fischer, J. 1985. The oxygen consumption of non-dormant and dormant larvae of Chironomus plumosus (Diptera). - Journal of Insect Physiology 31(10): 767-772. https://doi.org/10.1016/00221910(85)90069-1

Michailova, P. and Fischer, J. 1986. Chironomus vancouveri sp. n. from Canada (Diptera, Chironomidae). - Reichenbachia 23: 99-106.

Michailova, P. and Fischer, J. 1986. Speciation within the plumosus group of the genus Chironomus Meigen (Diptera, Chironomidae). - Zeitschrift für zoologische Systematik und Evolutionsforschung 24(3): 207-222.

Reist, A. and Fischer, J. 1987. Experimentelle Untersuchungen zur Einwirkung von Temperatur und Besiedlungsdichte auf die Entwicklung der Chironomus-Arten Ch. plumosus, Ch. nuditarsis und Ch. bernensis (Diptera). - Zoologische Jahrbücher. Abteilung für Systematik, Ökologie und Geographie der Tiere 114: 1-13.

Fischer, J. and Ineichen, H. 1988. The Diurnal Eclosion Activity of Chironomus nuditarsis (Diptera) in the Course of the Seasons. - Zoologische Jahrbücher. Abteilung für Systematik, Ökologie und Geographie der Tiere 115: 93-115.

Rychen Bangerter, B. and Fischer, J. 1989. Different Dormancy Response in the Sympatric Chironomus Species Ch. plumosus and Ch. nuditarsis. - Zoologische Jahrbücher. Abteilung für Systematik, Ökologie und Geographie der Tiere 116: 145-150.

Fischer, J., Ineichen, H. and Adamek, G. 1990. Circadian Clock and Eclosion Activity of Chironomus (Dip- 
tera, Chironomidae). - Zoologische Jahrbücher. Abteilung für Systematik, Ökologie und Geographie der Tiere 117: 317-329.

Michailova, P., Matena, J. and Fischer, J. 1990. The classification of different Chironomus plumosus (L.) populations after the homozygous inversion types of polytene chromosomes. In: Országh, I. (Ed.) $A b-$ stract Volume. $2^{\text {nd }}$ International Congress on Dipterology, August 27 - September 1 1990. Department of Zoology, Faculty of Natural Sciences, Comenius University Bratislava, p. 155.

Fischer, J. 1991. Zur Didaktik der klassischen Genetik und Cytologie. - Chemie und Biologie 35(3): 24-30.

Filippova, M.A., Kiknadze, I.I., Aimanova, K.G., Blinov, A.G., Fischer, J. and Kolesnikov, N.N. 1991. Chromosomal homologies among Chironomid species determined by in situ hybridization. In: van de Bund, W.J., Gardeniers, J.J.P. and Kraak, M.H.S. (Ed.) Abstract volume. $11^{\text {th }}$ International Symposium on Chironomidae, 12-14 August 1991. University of Amsterdam, p. 17.

Fischer, J. and Adamek, G. 1991. Eclosion behaviour of sympatric and allopatric Chironomus species. In: van de Bund, W.J., Gardeniers, J.J.P. and Kraak, M.H.S. (Ed.) Abstract volume. $11^{\text {th }}$ International Symposium on Chironomidae, 12-14 August 1991. University of Amsterdam, p. 18.

Filippova, M.A., Kiknadze, I.I., Aimanova, K.G., Fischer, J. and Blinov, A.G. 1992. Homology of Balbiani rings among chironomid species and localization of a new mobile element on the polytene chromosomes. van de Bund, W.J. and Kraak, M.H.S. (Ed.) Proceedings. $11^{\text {th }}$ International Symposium on Chironomidae, 12-14 August 1991. University of Amsterdam. - Netherlands Journal of Aquatic Ecology 26: $123-128$. 